\title{
Microbial community composition of transiently wetted Antarctic Dry Valley soils
}

\section{Thomas D. Niederberger ${ }^{1}$, Jill A. Sohm ${ }^{2}$, Troy E. Gunderson ${ }^{2}$, Alexander E. Parker ${ }^{3}{ }^{\prime}$, Joëlle Tirindelli $^{3}$, Douglas G. Capone ${ }^{2}$, Edward J. Carpenter ${ }^{3}$ and Stephen C. Cary ${ }^{1,4}$ *}

${ }^{1}$ College of Marine and Earth Sciences, University of Delaware, Lewes, DE, USA

${ }^{2}$ Wrigley Institute for Environmental Studies and Department of Biological Sciences, University of Southern California, Los Angeles, CA, USA

${ }^{3}$ Romberg Tiburon Center for Environmental Studies, San Francisco State University, Tiburon, CA, USA

${ }^{4}$ School of Science, University of Waikato, Hamilton, New Zealand

\section{Edited by:}

David Anthony Pearce, Northumbria

University, UK

\section{Reviewed by:}

M. J. L. Coolen, Woods Hole Oceanographic Institution, USA

Anne E. Taylor, Oregon State

University, USA

\section{${ }^{*}$ Correspondence:}

Stephen C. Cary, School of Science, University of Waikato, Private Bag 3105, Hamilton 3240, New Zealand e-mail: caryc@udel.edu

${ }^{\dagger}$ Present address:

Alexander E. Parker, California Maritime Academy, 200 Maritime Academy Drive, Vallejo, CA 94590, USA
During the summer months, wet (hyporheic) soils associated with ephemeral streams and lake edges in the Antarctic Dry Valleys (DVs) become hotspots of biological activity and are hypothesized to be an important source of carbon and nitrogen for arid DV soils. Recent research in the DV has focused on the geochemistry and microbial ecology of lakes and arid soils, with substantially less information being available on hyporheic soils. Here, we determined the unique properties of hyporheic microbial communities, resolved their relationship to environmental parameters and compared them to archetypal arid DV soils. Generally, $\mathrm{pH}$ increased and chlorophyll a concentrations decreased along transects from wet to arid soils (9.0 to $\sim 7.0$ for $\mathrm{pH}$ and $\sim 0.8$ to $\sim 5 \mu \mathrm{g} / \mathrm{cm}^{3}$ for chlorophyll a, respectively). Soil water content decreased to below $\sim 3 \%$ in the arid soils. Community fingerprintingbased principle component analyses revealed that bacterial communities formed distinct clusters specific to arid and wet soils; however, eukaryotic communities that clustered together did not have similar soil moisture content nor did they group together based on sampling location. Collectively, rRNA pyrosequencing indicated a considerably higher abundance of Cyanobacteria in wet soils and a higher abundance of Acidobacterial, Actinobacterial, Deinococcus/Thermus, Bacteroidetes, Firmicutes, Gemmatimonadetes, Nitrospira, and Planctomycetes in arid soils. The two most significant differences at the genus level were Gillisia signatures present in arid soils and chloroplast signatures related to Streptophyta that were common in wet soils. Fungal dominance was observed in arid soils and Viridiplantae were more common in wet soils. This research represents an indepth characterization of microbial communities inhabiting wet DV soils. Results indicate that the repeated wetting of hyporheic zones has a profound impact on the bacterial and eukaryotic communities inhabiting in these areas.

Keywords: Dry Valley, Antarctica, microbial diversity, microbial community, hyporheic

\section{INTRODUCTION}

The Antarctic continent is one of the most physically and chemically demanding environments on Earth and was once considered to be adverse to all life (Boyd et al., 1966). The extreme nature of this environment is exemplified in the Dry Valleys (DVs) of South Victoria Land, Eastern Antarctica, which comprise the largest contiguous ice-free region in Antarctica, with glaciated valley systems covering an area over $6000 \mathrm{~km}^{2}$ (Cary et al., 2010). Antarctic DV soil ecosystems are characterized by huge temporal variations in temperature and light regimes (Thompson et al., 1971; Vincent, 1988; Doran et al., 2002), steep chemical gradients, and a high incidence of solar radiation in austral summer (Smith et al., 1992; Dana et al., 1998). The microbes inhabiting these ice-free cold soil environments are subjected to extremely low nutrients (Vishniac, 1993) and low bioavailability of water with by high levels of salinity (Claridge and Campbell, 1977; Bockheim, 1997; Barrett et al., 2004). The additive effects of such extreme aridity, and widely fluctuating physiochemical conditions greatly impacts the adaptations and life cycle strategies used by the resident biota in these "cold deserts."

The biota within the DV mineral soils is comprised of bacteria, microalgae, fungi, and microbial feeding heterotrophs such as nematodes, rotifers, and tardigrades (Wynn-Williams, 1996; Moorhead et al., 2003); however, prokaryotes represent the greatest biomass in Antarctic ecosystems (Franzmann, 1996). Isolation and description of the microflora from the continent over the last six decades has yielded numerous novel microbial species (Johnson et al., 1978; Vishniac, 1993; de la Torre et al., 2003), but much remains unknown about the composition and ecosystem functioning of these microbial communities.

Early culture-based microbial studies (Cameron et al., 1970; Vishniac and Mainzer, 1972; Vincent, 1988; Wynn-Williams, 1990; Friedmann, 1993; Vishniac, 1993) suggested that the soil bacterial diversity and abundance in these cold desert areas was extremely low, as might be predicted by the extreme nature of the system. This is in stark contrast to subsequent work in nutrient- and 
water-rich Antarctic 'ornithogenic' and fell-field soils, and lake sediments showing vastly higher microbial abundance based on direct counts (Ramsay and Stannard, 1986; Wynn-Williams, 1990; Sjoling and Cowan, 2003). However, not until recent molecularbased phylogenetic studies on DV microbial populations (de la Torre et al., 2003; Smith et al., 2006; Niederberger et al., 2008) was the true, and surprisingly high diversity of microorganisms in this environment revealed (Cary et al., 2010). This was an unexpected finding considering the extreme nature and trophic simplicity of the system.

While considerable research has focused on the geochemistry and microbial ecology of the permanently ice covered lakes (Priscu et al., 1998; Gordon et al., 2000; Berry Lyons et al., 2001; Berry Lyons, 2004) and the arid DV soils (Smith et al., 2006, 2010; Wood et al., 2008; Babalola et al., 2009; Pointing et al., 2009; Lee et al., 2012) there is substantially less information on the ecology and biogeochemistry of the streams feeding these lakes and the wet moated areas surrounding lakes (Stanish et al., 2013). DV lakes are fed by transient glacial melt streams that typically flow for 6-12 weeks during the austral summer and are virtually the only source of water for the DV (Gooseff et al., 2006). The wet zone of soil which extends below and to the sides of glacial streams (and lake edges), defined as the hyporheic zone, can be up to about $70 \mathrm{~cm}$ deep (to the permafrost depth) and extend several meters to each side (Gooseff et al., 2006). A feature of many of the hyporheic zones is the conspicuous presence of cyanobacteria in biological crust communities. These communities vary greatly in the abundance and types of dominant cyanobacteria and can vary from one stream to another and from one valley to another (Broady, 1982; Vincent and HowardWilliams, 1986; Vincent et al., 1993; McKnight and Tate, 1997; Vincent, 2000). During the austral winter these communities are essentially freeze-dried and inactive. Various studies have demonstrated that during the warmer summer months DV hyporheic soils are hotspots of biological cycling (Runkel et al., 1998; McKnight et al., 1999, 2007; Gooseff et al., 2003), undertake high levels of $\mathrm{N}_{2}$ fixation (Howard-Williams et al., 1989; Niederberger et al., 2012) and are thought to be an important source of organic $C$ and $\mathrm{N}$ to the surrounding soils due to aeolian-associated distribution of crust detritus (Hopkins et al., 2006a,b; Barrett et al., 2007; Novis et al., 2007). As a result, primary productivity and $\mathrm{N}_{2}$ fixation at these wet sites may represent a major source of $\mathrm{C}$ and $\mathrm{N}$ to an otherwise nutrient-limited system. Although the significance of these transiently wet sites is clear, there is little information on the microbial assemblages inhabiting these soils. Recent work on sediments in streams shows specific diatoms and bacteria co-occur (Stanish et al., 2013), but our study presented here provides the first comprehensive view of microbial communities (prokaryotic and eukaryotic) in the wet regions adjacent to streams and lakes as compared to arid soils in the DV. Therefore, the objective of this study was to add to this knowledge gap and characterize and compare microbial communities of both wet (hyporheic) soil zones and local bulk arid soils of the Antarctic DV. Detailed rRNA gene-based analyses was used to shed light on the major organisms inhabiting these soils and indicate that microbial communities differ considerably between these contrasting biotopes.

\section{MATERIALS AND METHODS COLLECTION AND SOIL ANALYSES}

Sampling sites and methodology is as described previously (Niederberger etal., 2012). Transects ranging between 3.7 and $20 \mathrm{~m}$ in length were sampled that consisted of four sampling sites originating from site 1 defined as a 'wet' zone (sampling within the lake/stream edge) extending through moist soil zones containing crust communities (sites 2 and 3 ) to the final site 4 located in a typical DV desert mineral soil. A total of 10 transects were sampled during two separate field seasons (January and December, 2009) as listed in Table 1. Transects collected during the initial field season were also described in a previous study describing $\mathrm{N}_{2}$ fixation activities in the wet soils (Niederberger et al., 2012). The locations of the sampled transects are presented in Figure $\mathbf{1}$ and included: the northern shore of Miers Lake (ML) in Miers Valley; sites both at the source (Miers Glacier) and downstream of Miers Stream (MS) which feeds into ML; a pond situated over the southern ridge of Miers Valley [Hidden Valley (HV)]; and two lake systems [Nostoc Pond (NP) and Buddha Lake (BL)] located over the north ridge of Miers Valley. Soil $\mathrm{pH}$, gravimetric water content, chlorophyll $a$, nitrate and nitrite, ammonium, silicate, orthophosphate, and cell counts were determined as described previously (Niederberger etal., 2012). Nutrient concentrations were not determined for some of the highly arid soils due to the lack of pore water.

\section{DNA EXTRACTION AND TERMINAL-RESTRICTION FRAGMENT LENGTH POLYMORPHISM (T-RFLP) ANALYSES}

DNA was isolated from homogenized soil sampled soils using the Powersoil ${ }^{\mathrm{TM}}$ DNA isolation kit (MOBIO) as per manufacturer's instructions with all terminal-restriction fragment length polymorphisms (T-RFLPs) based on pooled triplicate PCR assays (Niederberger et al., 2012). Bacterial T-RFLP analyses were undertaken according to Danovaro et al. (2006). Eukaryotic T-RFLP was performed as described by Díez et al. (2001) with the exception of using a single restriction endonuclease (MspI; New England BioLabs Inc.) as previously performed on Antarctic soils (Pointing et al., 2009). Digestions comprised $3 \mathrm{~h}$ incubation at $37^{\circ} \mathrm{C}$ with an enzyme inactivation step of $80^{\circ} \mathrm{C}$ for $20 \mathrm{~min}$. Terminal-fragments were sized using the MegaBACE system (Amersham) at the Waikato DNA Sequencing Facility (University of Waikato, Hamilton, New Zealand). Fluorescent peak data were aligned using the T-REX online platform (Culman et al., 2009) and the resulting TRF absence/presence data matrix imported into PRIMER6 (Primer-E Ltd., Plymouth, UK) for statistical analyses. Community comparisons were performed via principle component analyses (PCAs) with percentage similarity between community fingerprints overlaid as detailed in the Primer v6: User Manual/Tutorial (Clarke and Gorley, 2006), and BEST analyses used to reveal any abiotic factors that best explain the observed community fingerprints (Clarke and Gorley, 2006).

\section{AMPLICON PYROSEOUENCING AND ASSOCIATED ANALYSES}

Tagged amplicon pyrosequencing of the $\mathrm{V} 1$ to $\mathrm{V} 3$ region of the $16 \mathrm{~S}$ and 18S rRNA gene (primer pairs 28F-519R and euk7Feuk570R, respectively) was performed on DNA extracts by the Research and Testing Laboratories located in Lubbock, TX 


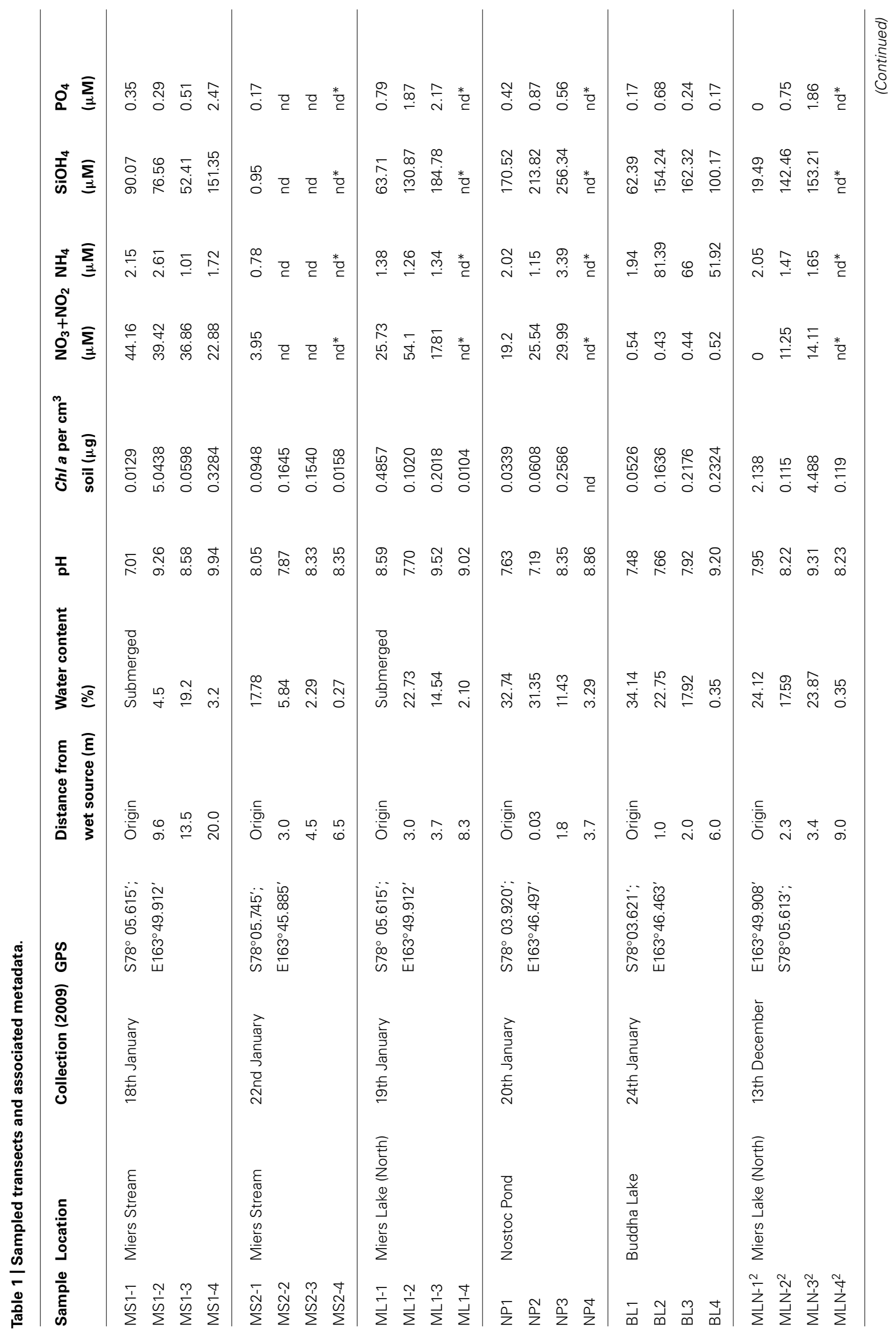




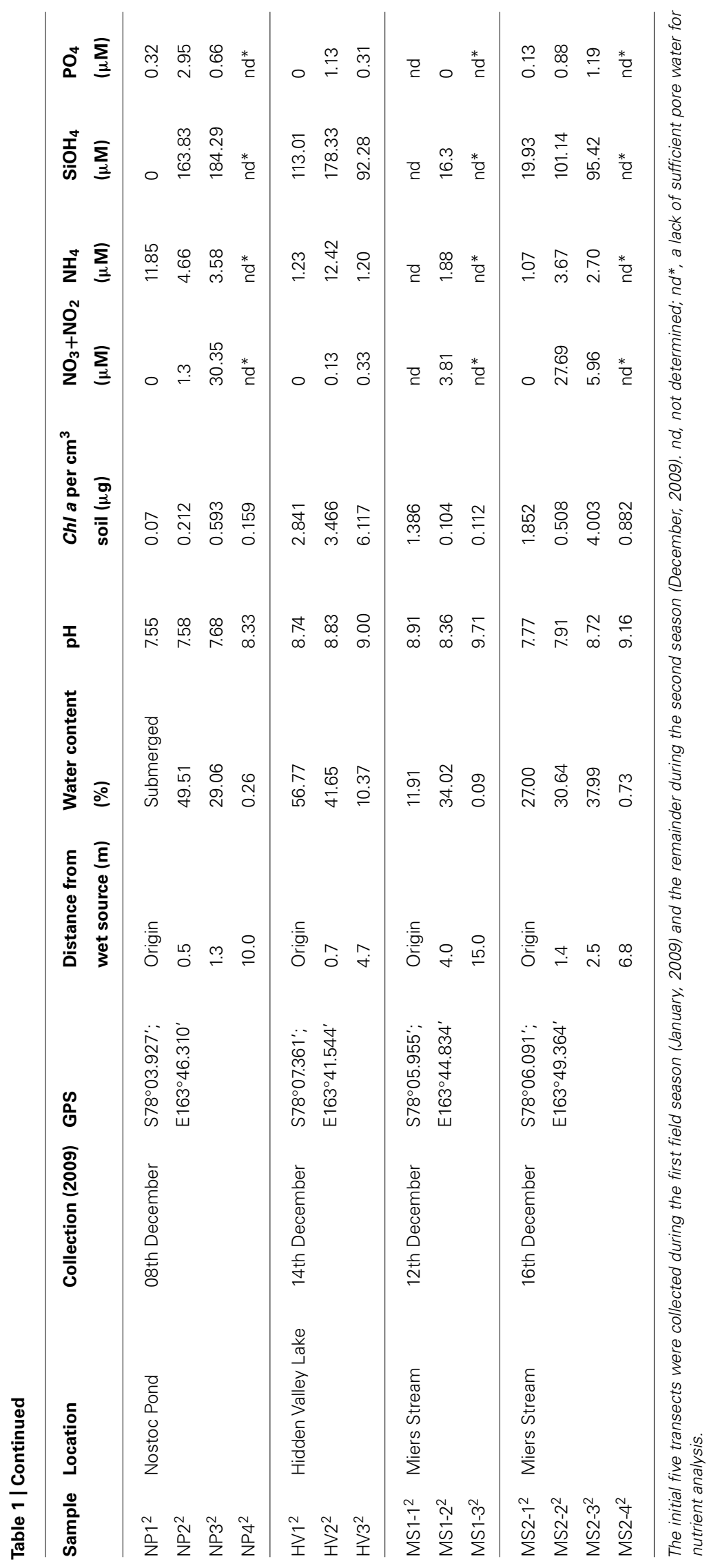




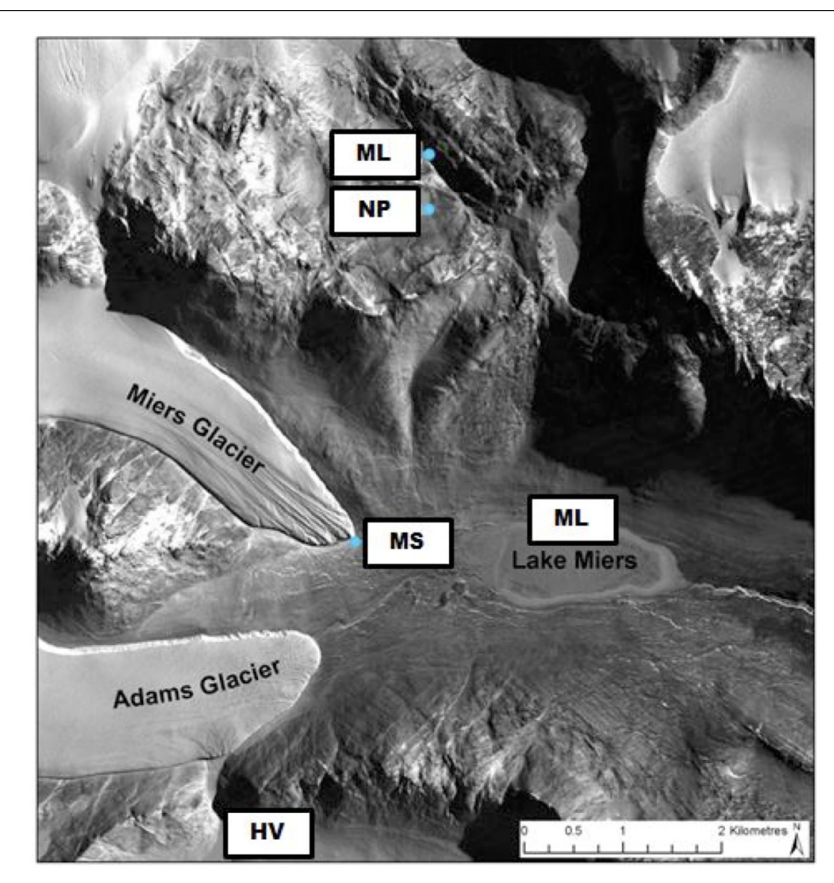

FIGURE 1 | Location of sampling sites.

(www.researchandtesting.com) using FLX technology (Roche). The pyrosequencing datasets generated in this study are deposited in the European Nucleotide Archive, under accession number PRJEB7939 (ERP008940). Sequence data were quality trimmed (>200 bp) and processed using defaults within the Quantitative Insights Into Microbial Ecology (QIIME) toolkit (Caporaso et al., 2010). In brief, sequences were split according to tags and binned into operational taxonomic units (OTUs) at 95\% similarity. Bacterial taxonomic assignment was undertaken on all quality trimmed sequences using the online Ribosomal Database Project (RDP) classifier tool [at 80\% confidence level (Cole et al., 2009)] . Eukaryotic taxonomic assignment was performed within the QIIME toolkit using the Basic Local Alignment Search Tool (BLAST) upon a representative sequence from each OTU against the modified SILVA $18 \mathrm{~S}$ rRNA gene database (Pruesse et al., 2007) as obtained from mothur (Schloss et al., 2009). The online RDP Library compare tool (Cole et al., 2009) was used to evaluate any significant differences in bacterial communities between combined wet and dry soil sequence libraries, with 9039 sequences randomly removed from the NP2 library to ensure the number of sequences remained below the maximum limit of 40,000 .

\section{RESULTS}

Samples were collected along transects extending through wet/hyporheic soils from a wet source represented by a lake or stream to typical bulk arid DV soil. Water content in these soils generally decreased along the transects to below $\sim 3 \%$ in the arid soils, with a concurrent increase in the $\mathrm{pH}$ of the soils from submerged to arid soils (Table 1). Chlorophyll $a$ concentrations were highest in wet soils (up to $\sim 5 \mu \mathrm{g} / \mathrm{cm}^{3}$ ) with no obvious correlations between nutrient concentrations and distance from the water source.

Principle component analyses of bacterial T-RFLP fingerprints revealed that the arid soils ( $0-5 \%$ water moisture) formed a tight cluster grouping at $40 \%$ similarity (Figure 2A). Whereas, in general, the wetter sites ( $>5 \%$ moisture content) formed two major clusters grouping at $40 \%$ similarity, with one cluster comprised of sites located in Miers Valley (i.e., stream and lake systems) and a second cluster consisting of transects located in both the northern (NP and BL) and southern sites (Hidden Valley). In contrast to the bacterial profiles, high spatial variability was observed for the eukaryotic T-RFLP-based PCA profiles (Figure 2B). BEST analysis showed that only a small amount of community structure could be attributed to the environmental parameters measured, bacterial community structure best correlated to distance from water source, $\mathrm{pH}$ and $\mathrm{NH}_{4}(\varrho=0.214)$, and the eukaryote community to distance from water source, $\mathrm{pH}$ and $\%$ moisture $(\varrho=0.202)$.

To further elucidate differences in microbial community structure between wet and arid soils, amplicon pyrosequencing of bacterial and eukaryotic rRNA genes was undertaken on wet and arid soil samples from representative transects collected in January 2009 (transects: BL, ML1) and December 2009 (transects: MS1 and NP). These sites were selected based on clustering PCA results (i.e., wet vs. dry sites were distinctly separated in PCA results) and it was ensured that both a wet and arid site from the same transect was sequenced. Rarefaction analyses at 95\% for all sites indicate adequate sampling size with curves reaching or nearing plateau (results not shown). Obvious differences in bacterial composition between wet and dry soil biotopes include increased representation of Acidobacteria and Actinobacteria in arid soils and, with the exception of NP, cyanobacteria being more highly represented in wetter soils (Figure 3). Specifically, Acidobacteria comprised $\sim<2.5 \%$ of the total signatures detected in wet soils and $1.3-11.0 \%$ in arid soils while Actinobacteria comprised $\sim<7.5 \%$ in wet soils and $\sim 4.7-37.0 \%$ in arid soils. As expected, Cyanobacteria comprised $\sim 10-47 \%$ of the total sequences in wet soils that had visible microbial crusts and $<7 \%$ for arid soils of BL, ML, MS ( $33 \%$ for NP). Of note, the Deinococcus-Thermus group was generally present in arid soils (0.09-6.0\%), but very low to undetected in the wet soils $(<0.02 \%)$.

To elucidate overall shared differences of the bacterial rRNA signatures between wet and arid soils, sequences from all wet sites (i.e., BL2, ML1.2, MS1.2, and NP2) were combined and compared to combined arid sites (i.e., BL4, ML1.4, MS1.3, and NP4) using the RDP Library compare tool. Nine phyla and 36 genera showed highly significant differences between wet and arid soils (Table 2). Differences in bacterial phyla composition observed when comparing wet and arid soils within each transect (i.e., Acidobacteria, Actinobacteria, Cyanobacteria and DeinococcusThermus, Figure 3) are supported by the combined analysis which also shows that Bacteroidetes, Firmicutes, Gemmatimonadetes, Nitrospira, and Planctomycetes were significantly more abundant in arid samples (Table 2). The most significant differences at the genus level was the detection of Gillisia signatures in arid soils ( $\sim 3.7 \%$ of the combined sequences) but undetected in wet 

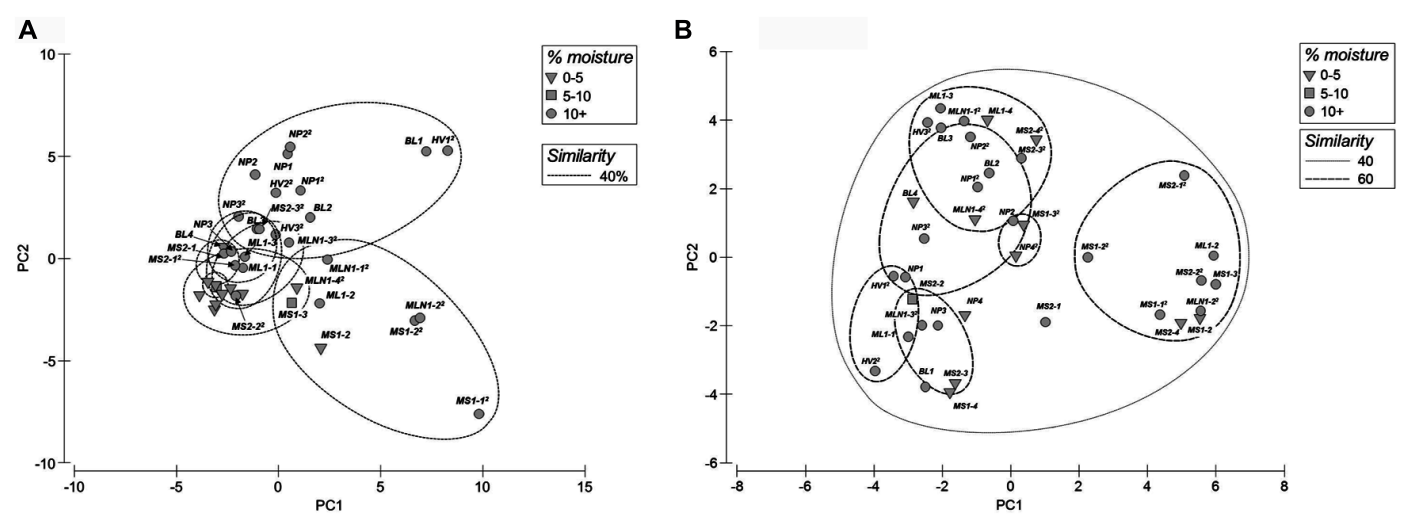

FIGURE 2 | Principal component analyses of T-RFLP fingerprints from both bacterial (A) and eukaryotic (B) communities (MS1-1 not included in plots).

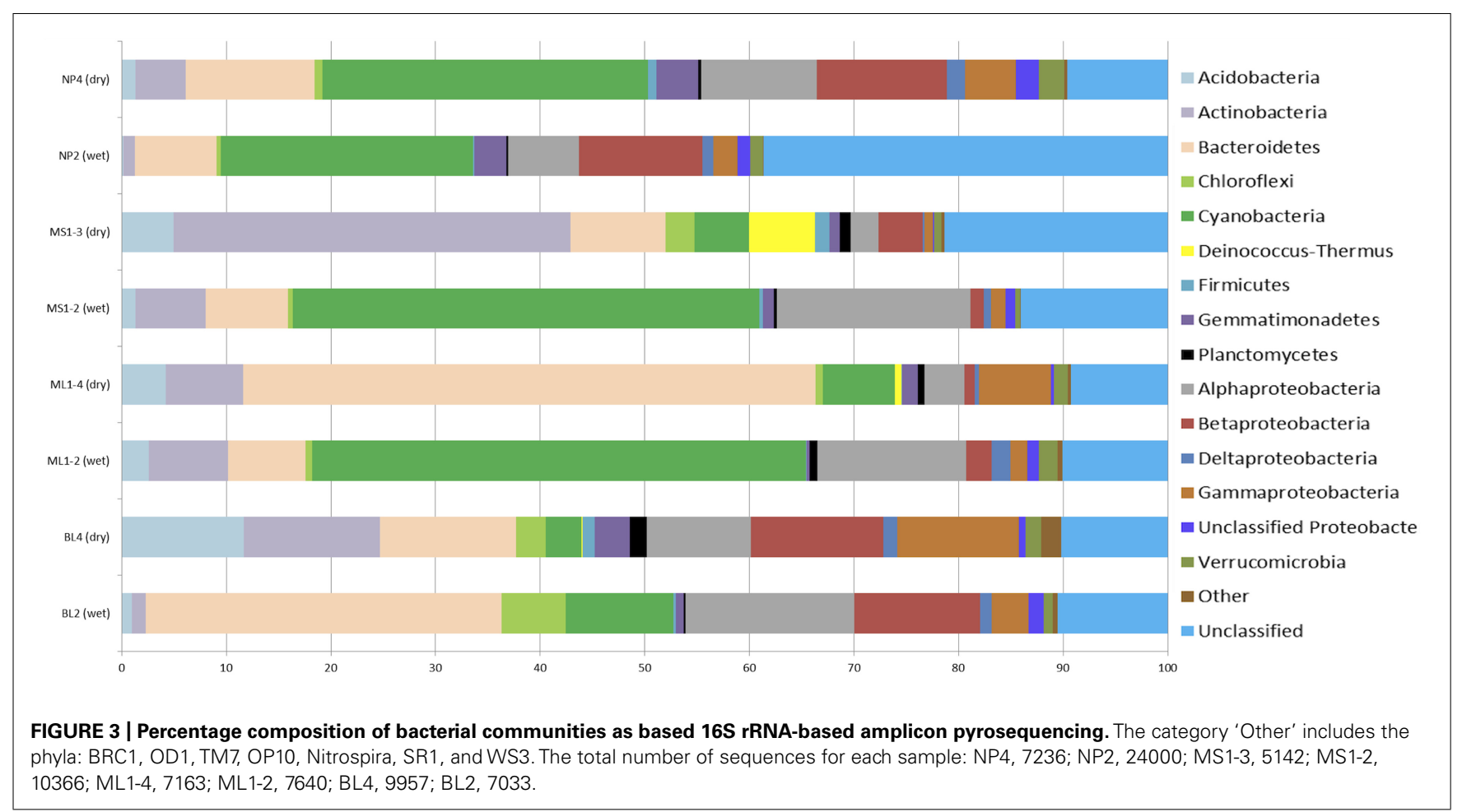

soils and the chloroplast Streptophyta-related signature common in wet soils ( $\sim 12.0 \%$ of combined sequences) while only a single sequence detected in arid soils. See Table 2 for the list of the most significant results ( $e$ values $\leq 6.00 \mathrm{E}^{-14}$ ).

For Eukarya (Figure 4), obvious differences included a fungal dominance in arid soils $(\sim 41-70 \%)$ with the exception of BL $(\sim 5.5 \%)$ and both the Haptophyceae (dominant signatures related to Imantonia, Cruciplacolithus, and Reticulosphaera) and Stramenopiles (dominant signatures being Desmarestia, Paraphysomonas, and Chrysococcus) being highly represented in arid soils ( $\sim 0.1-20 \%$ and $\sim 3.5-9.5 \%$, respectively) as opposed to wet soils ( $\sim 0.0-0.1 \%$ and $\sim 0.0-0.4 \%$, respectively). Another obvious trend was Spathidium (of the Alveolata) being highly represented in arid soils (1.6-8.6\% of total community), but rare $(0.04 \%)$ to undetected in wetted soils. Viridiplantae (mainly Streptophyta signatures, as reflecting $16 \mathrm{~S}$ rRNA results) were more common in wet soils, 50-99\% for BL, ML, and MS (with the exception of $\mathrm{NP}$, at $1.2 \%$ ), with the number of sequences detected in arid soils being considerably lower (i.e., $\sim 4-16 \%$ for BL, ML and MS and $\sim 18 \%$ for NP).

\section{DISCUSSION}

During the summer months hyporheic soils surrounding ephemeral DV streams and lake edges are hotspots of biological activity (Runkel etal., 1998; McKnight et al., 1999, 2007; Gooseff et al., 2003; Niederberger et al., 2012), and are hypothesized to be an important source of carbon and nitrogen to the surrounding soils (Hopkins etal., 2006a,b; Barrett etal., 
Table 2 | The most significant results ( $e$ values $\leq 6.00 \mathrm{E}-14)$ at the genus level from the comparison of the combined wet soil-associated bacterial sequences (39,999 sequences from BL2, ML1-2, MS1-2, and NP2) with combined arid-associated sequences (29,498 sequences from BL4, ML1-4, MS1-3, and NP4) using the online RDP library compare tool.

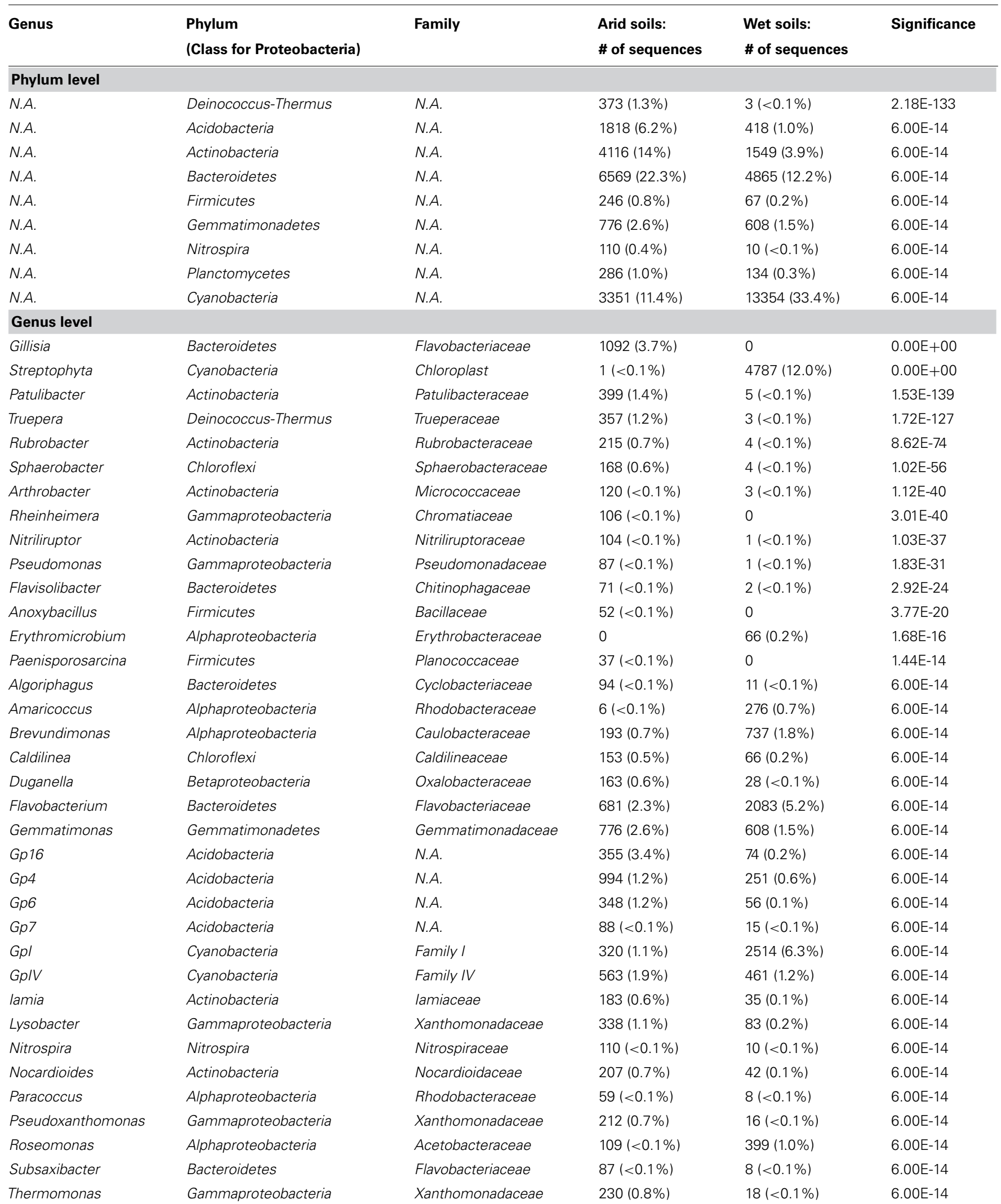




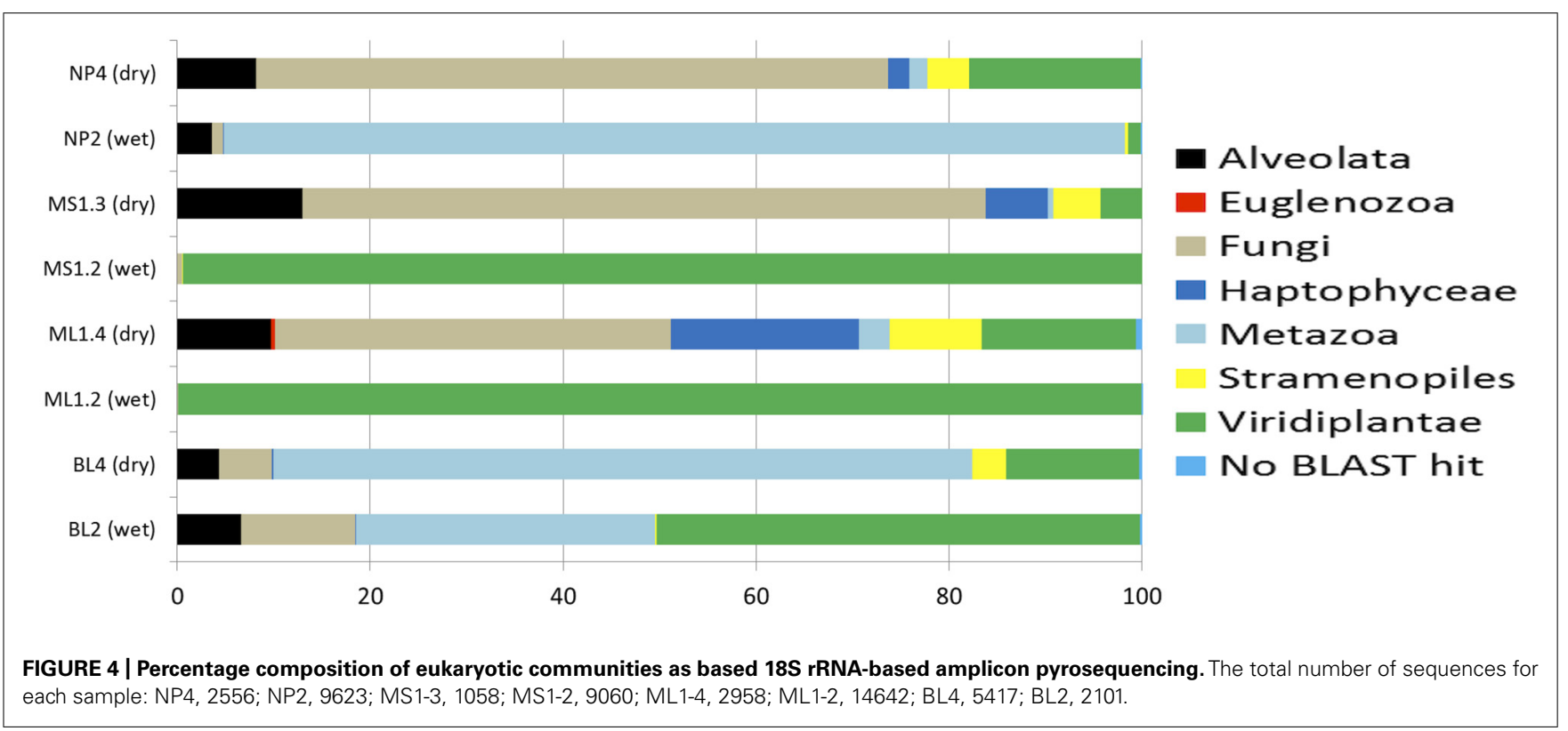

2007; Novis etal., 2007). Although the significance of these transiently wet sites is acknowledged, there is limited information on the microbial communities inhabiting these soils. Our previous research has identified microbial assemblages in these wet soils that have the potential for $\mathrm{N}_{2}$ fixation with high rates of $\mathrm{N}_{2}$ fixation that may in-part be linked to sulfate reduction (Niederberger et al., 2012). Stanish et al. (2013) also recently reported in-depth analyses of microbial community structure of mats located in DV streams, the results of which showed significant relationships between diatom and bacterial communities and indicated species interactions between specific taxa. Moreover, results suggested that stream flow regime may influence the overall community structure with a lack of relationship between heterotrophic microbial diversity and nutrient concentrations (Stanish et al., 2013). It therefore seems that both species interactions and niche specific processes have an influence in defining community structure in DV microbial mats.

Our studies focused instead on wet soils at the edge of and adjacent to DV stream, lakes, and ponds (the hyporheic zone). Our transects, with sites sampled from the origin in wet soils and extending to arid soils varied in moisture content, with moisture contents at the farthest "point 4" sampling site being in the range typically reported for archetypal DV soils, i.e., $\sim<5 \%$ (Niederberger etal., 2008; Cary et al., 2010; Lee etal., 2012; Tiao et al., 2012). Arid soils were highly alkaline ( 9.0) as expected in the Mier's Valley locale (Lee et al., 2012), with values decreasing along the moisture gradient to near neutral levels at the leached wet origin soils. Due to the presence of cyanobacterial crust communities, wetter sites contained elevated chlorophyll $a$ concentrations relative to arid soils.

Various studies have attempted to link physicochemical properties with soil microbial ecology in the DV soils (Virginia and Wall, 1999; Niederberger et al., 2008; Soo et al., 2009; Smith et al., 2010; Zeglin etal., 2011; Lee etal., 2012; Stanish et al., 2013).
Water obviously drives biomass formation in DV soils as evidenced by large amounts of biofilm/biomass presence at lake edges; however, water may not be the primary driver of the presence of all organisms in DV soil habitats. For example, water does not appear to be the limiting factor for nematode abundance in DV soil habitats (Virginia and Wall, 1999) and water content is a poor indicator of cyanobacteria distribution in DV soils with other variables such as soil elemental composition or conductivity hypothesized to define habitat suitability (Wood et al., 2008). More recently, Lee et al. (2012) examined microbial communities from four geographically distinct DV soils and report significantly different communities between sites that were correlated to salt content, altitude and $\mathrm{Cu}^{2+}$. Smith et al. (2010) have also noted high spatial variability of bacterial communities in DV soils; however in their study, microbial signatures were correlated with soil moisture and $\mathrm{pH}(\varrho=0.564)$. In a related study describing communities in DV hyporheic zones water content was strongly related to community composition with microbial diversity related to soil conductivity (Zeglin et al., 2011). Conductivity has also recently been shown to influence cyanobacterial diversity in microbial mats associated with streams in the DV (Stanish et al., 2013). Analogous to these collective studies, our work also suggests that water drives bacterial community composition as evidenced by bacterial T-RFLP fingerprints of drier sites clustering together within PCA ordinations. Weak correlations $(\varrho=0.214)$ were identified for bacterial community fingerprints that were most closely related to $\mathrm{pH}, \mathrm{NH}_{4}$ and the distance from the water source [as previously postulated (Niederberger etal., 2012)] which could also be perceived as directly relating to percent moisture content. As previously hypothesized for nematode distribution (Virginia and Wall, 1999), moisture was not a strong driver of Eukarya presence in this study, with no similarity observed between wet or dry samples on PCA ordinations and only weak correlations to distance from source, \% moisture and $\mathrm{pH}(\varrho=0.202)$. Collectively, these studies suggest 
that a complex set of abiotic factors define habitat suitability for microbial communities in DV soils that currently remain unresolved.

Microbial communities in the arid DV soils have recently been shown to be highly localized with structurally and phlyogenetically distinct populations existing in geographically disparate sites, suggesting that communities maybe endemic to each DV location (Lee et al., 2012). This is in contrast to the hypothesis that the intense DV winds might distribute microbes throughout the valleys. In fact, high-throughput rRNA sequencing revealed that microbial signatures in aerosols and nearby soils were dominated by different phyla (Bottos et al., 2014) hinting that aeolian-based movement of soils and the associated communities among valleys may be limited and therefore local physicochemical factors will have a major role in shaping community structure and colonization of DV soils (Lee et al., 2012). This insight is also reflected in PCA ordinations of bacterial communities in wetter sites in our study ( $>5 \%$ moisture content), as sites located in Miers Valley (i.e., stream and lake systems) clustered together and transects located in adjacent northern (NP and BL) and southern sites (Hidden Valley) formed another cluster. These observed differences may be due to local physicochemical factors selecting for these communities, e.g., the source of the water and the local mineralogy. Yet, in contrast to the findings by Lee et al. (2012) bacterial fingerprints from all arid sites clustered tightly together within PCA ordinations, indicating a commonality of community structure between these particular arid soils. This may however be attributable to the different geographical scales between the two studies, with Lee et al. (2012) analyzing samples from four geographically disparate Valleys as opposed to the more local samples described in this study. Further work is therefore required to illuminate the spatial distribution and possible biogeography of microbial communities between arid DV soils.

Wet soils were dominated by Cyanobacterial signatures with the exception of BL2 where Bacteroidetes comprised $\sim 34 \%$ of the community as compared to $\sim 10 \%$ for cyanobacteria. Bacteroidetes related sequences also made up a large proportion of the signatures detected in both the wet and dry soils $(\sim 7-$ $55 \%$ ) at the other transect sites. In a similar study (Stanish et al., 2013), Bacteroidetes were the most abundant heterotrophic taxa detected in DV microbial mats (including MS). Globally, Bacteroidetes are common members of microbial mats and are suited to these types of environments due to their ability to degrade various organic compounds (Stanish et al., 2013), and as witnessed in the RDP-based comparison, there was a notable significant enrichment of Flavobacterium-related signatures of the Bacteroidetes in the wet soils. In contrast to this finding, the Gillisia genera of the Bacteroidetes was more abundant in arid soils and was the most significant difference between the wet and arid soils (discussed in detail below). Our results also mirror those reported by Stanish et al. (2013) whereby, Alphaproteobacteria and/or Betaproteobacteria were also dominant members of the microbial communities inhabiting ephemerally wet DV soils. Although RDP-based comparative analyses did not indicate that these phyla differed significantly between collective wet and arid soil sequences, certain genera within these phyla were significantly higher in wet soils, including Erythromicrobium [a freshwater, obligately aerobic, anoxygenic photosynthetic bacterium (Yurkov et al., 1994)], Amaricoccus [an aerobic chemoheterotroph (Maszenan et al., 1997)], Brevundimonas [a radiation resistant organism previously isolated in Antarctic soils (Dartnell et al., 2010)], and Roseomonas [a pink-pigmented organism with an oxidative metabolism (Zhang et al., 2008)].

As expected (Niederberger et al., 2012), wetter soils had higher cyanobacterial presence compared to dry soils. Due to the RDP classifier employing the Bergeys Manual-based cyanobacterial classification of family level groupings, GpI-XIII (Bolhuis and Stal, 2011), the cyanobacterial signatures are not classified any deeper. The vast proportion of cyanobacterial signatures for all sites were unclassified with the GpI group of the Family I phylogenetic clade dominating cyanobacterial signatures in both wet and arid soils. GpI signatures were generally higher in wet soils, $\sim 2-12 \%$ of the total community $(0.2-3 \%$ in arid soils). The GpIV group of cyanobacteria were the second most dominant cyanobacterial signature with higher numbers in arid soils of BL and ML ( $\sim 0.1$ and $6 \%$ respectively) as opposed to wet ( 0.04 and $3 \%)$, and similar concentrations in wet and arid soils for MS and NP ( $\sim 2$ and $0.2 \%$, respectively). However, of most interest is that the fact that RDP-based comparisons of combined signatures indicate significantly higher GpI signatures in wet soils, with GpIV signatures significantly higher in drier soils; therefore, these two groups of organisms may be adapted to their respective contrasting soil biotopes. Significantly higher quantities of chloroplast signatures were also detected in the wet soils at ML and MS sites (Table 2) that were almost exclusively related to the Streptophyta. Members of this green algal group inhabit both Arctic and Antarctic environments and have been studied due to their exposure to stressful environmental conditions including desiccation, high irradiation and UV levels (Kaplan et al., 2013). The GpI and IV groups of cyanobacteria have also been amongst the most dominant signatures detected in other environments that are exposed to sporadic, ephemeral wetting events including coastal microbial mats (Bolhuis and Stal, 2011) with the GpI group being abundant in Arctic snow layers (Møller et al., 2013). Eukarya presence in the DV soils also reflected previous studies, with a fungal dominance in arid soils and Viridiplantae in wet soils (Fell et al., 2006; Ruisi et al., 2007; Cary et al., 2010). These results therefore suggest the presence of cyanobacterial and algal species that are adapted to both the transient availability of water and inherent stressful conditions in these cold DV soils.

Pointing et al. (2009) have reported low or absent cyanobacterial signatures in arid soils of the McKelvey Valley, with cyanobacterial signatures being absent at all arid sites in the molecular-based studies by Niederberger et al. (2008), Smith et al. (2010), and Lee et al. (2012). Yet, at least in one case this has been attributed to PCR bias via use of a non-specific primer (Lee et al., 2012). Collectively, a higher abundance of signatures from the phyla, Acidobacteria, Actinobacteria, Deinococcus/Thermus, Bacteroidetes, Firmicutes, Gemmatimonadetes, Nitrospira, and Planctomycetes were detected in arid soils as compared to wet soils with various genera of these phyla being significantly more abundant in arid soils (Table 2). The most significant of these 
at the genus level was the presence of Gillisia in combined arid soils $(3.9 \%)$, but a complete absence in wet soils. Cultured and characterized representatives of the Gillisia genera are typically psychrophilic, chemoheterotrophic organisms isolated from Antarctica habitats; however, unexpectedly, these species have been isolated from wet biotopes including mats from Lake Fryxell (Van Trappen etal., 2004) and Antarctic maritime habitats (Bowman and Nichols, 2005). Various studies have proven that Actinobacteria and/or Acidobacteria are dominant members of arid DV soils (Smith et al., 2006; Niederberger et al., 2008; Pointing et al., 2009; Lee et al., 2012; Bottos et al., 2014) and that the Deinococcus/Thermus group maybe specific to low-productivity DV soils (Niederberger etal., 2008). Recently, the Deinococcus class of microorganisms have been shown to form a distinct distribution pattern in DV stream associated mats (Stanish et al., 2013) with higher abundances linked to their inherent high-UV tolerance. Radiation resistant signatures related to Truepera of the Deinococcus/Thermus group and Actinobacterial members of the Rubrobacteridae, e.g., Rubrobacter and Patulibacter were also detected in our study, and continue to be revealed as dominant members of arid DV biotopes (Carpenter et al., 2000; Aislabie et al., 2006; Smith et al., 2006; Shravage et al., 2007; Niederberger et al., 2008; Lee et al., 2012). Likewise, the eukaryote, Spathidium was notably higher in dry soils which can be attributed to their ability to survive periods of dryness via dormant resting stages (cysts; Foissner, 1974).

In contrast to archetypal arid DV desert soils, few studies have applied molecular-based techniques on microbial communities inhabiting wet/high productivity sites (Niederberger et al., 2008, 2012; Zeglin et al., 2011; Stanish et al., 2013). This research represents the first in-depth characterization of both bacterial and eukaryotic communities inhabiting wet DV soils adding to the knowledge of these environments. A large percentage of bacterial signatures also remain unidentified as is typically reported in studies utilizing rRNA-based molecular techniques to survey DV environments (Niederberger et al., 2008; Lee et al., 2012). However, it is important to recognize that due to inherent PCR-biases and the presence of dead cells and/or naked DNA, these analyses may not reflect the true diversity of DV communities. It is therefore suggested that future studies incorporate microscopybased methods such as fluorescent in situ hybridization (FISH) to reveal the true diversity and spatial distribution of these microorganisms in DV soil biotopes. Although this work represents the first major in-depth sequencing effort of hyporheic DV soils uncovering both diversity and identify of microbial inhabitants, the long-term goal of elucidating the associated biological function and reasons for their biogeography remains unresolved.

\section{ACKNOWLEDGMENTS}

We would like to thank the staff at the United States Antarctic Program, as well as Antarctica New Zealand, and the Foundation for Research in Science and Technology, New Zealand, for logistical support while in the field. This research was supported by National Science Foundation Grants ANT 0739633 (to Douglas G. Capone), ANT 0739640 (to Edward J. Carpenter), and ANT 0739648 and 0944560 (to Stephen C. Cary).

\section{REFERENCES}

Aislabie, J. M., Chhour, K.-L., Saul, D. J., Miyauchi, S., Ayton, J., Paetzold, R. F., et al. (2006). Dominant bacteria in soils of Marble Point and Wright Valley, Victoria Land, Antarctica. Soil Biol. Biochem. 38, 3041-3056. doi: 10.1016/j.soilbio.2006.02.018

Babalola, O. O., Kirby, B. M., Le Roes-Hill, M., Cook, A. E., Cary, S. C., Burton, S. G., et al. (2009). Phylogenetic analysis of actinobacterial populations associated with Antarctic Dry Valley mineral soils. Environ. Microbiol. 11, 566-576. doi: 10.1111/j.1462-2920.2008.01809.x

Barrett, J. E., Virginia, R. A., Lyons, W. B., McKnight, D. M., Priscu, J. C., Doran, P. T., et al. (2007). Biogeochemical stoichiometry of Antarctic Dry Valley ecosystems. J. Geophys. Res. 112, 1-12. doi: 10.1029/2005JG000141

Barrett, J. E., Virginia, R. A., Wall, D. H., Parsons, A. N., Powers, L. E., and Burkins, M. B. (2004). Variation in biogeochemistry and soil biodiversity across spatial scales in a polar desert ecosystem. Ecology 85, 3105-3118. doi: 10.1890/ 03-0213

Berry Lyons, W. (2004). The geochemistry and biogeochemistry of the McMurdo Dry Valleys, Antarctica. Aquat. Geochem. 10, 197-198. doi: 10.1007/s10498-0042258-y

Berry Lyons, W., Welch, K. A., Priscu, J. C., Labourn-Parr, J., Moorhead, D. L., McKnight, D. M., et al. (2001). The McMurdo Dry Valleys long-term ecological research program: new understanding of the biogeochemistry of the Dry Valley Lakes: a review. Polar Geogr. 25, 202-207. doi: 10.1080/108893701 09377713

Bockheim, J. G. (1997). Properties and classification of cold desert soils from Antarctica. Science 231, 224-231. doi: 10.2136/sssaj1997.03615995006100 010031x

Bolhuis, H., and Stal, L. J. (2011). Analysis of bacterial and archaeal diversity in coastal microbial mats using massive parallel $16 \mathrm{~S}$ rRNA gene tag sequencing. ISME J. 5, 1701-1712. doi: 10.1038/ismej.2011.52

Bottos, E., Woo, A., Zawar-Reza, P., Pointing, S., and Cary, S. (2014). Airborne bacterial populations above desert soils of the McMurdo Dry Valleys, Antarctica. Microb. Ecol. 67, 120-128. doi: 10.1007/s00248-013-0296-y

Bowman, J. P., and Nichols, D. S. (2005). Novel members of the family Flavobacteriaceae from Antarctic maritime habitats including Subsaximicrobium wynnwilliamsii gen. nov., sp. nov., Subsaximicrobium saxinquilinus sp. nov., Subsaxibacter broadyi gen. nov., sp. nov., Lacinutrix copepodicola gen. Int. J. Syst. Evol. Microbiol. 55, 1471-1486. doi: 10.1099/ijs.0.63527-0

Boyd, W. L., Staley, J. T., and Boyd, J. W. (1966). "Ecology of soil microorganisms of Antarctica," in Antarctic Soils and Soil Forming Processes, Antarctic Research Series Volume 8, ed. J. C. F. Tedrow (Washington, DC: American Geophysical Union), 125-160.

Broady, P. A. (1982). Taxonomy and ecology of algae in a freshwater stream in Taylor Valley, Victoria Land, Antarctica. Arch. Hydrobiol. Suppl. Algol. Stud. 32, 331-349.

Cameron, R. E., King, J., and David, C. N. (1970). "Microbial ecology and microclimatology of soil sites in Dry Valleys of Southern Victoria Land, Antarctica," in Antarctic Ecology, ed. M. W. Holdgate (London: Academic Press), 702-716.

Caporaso, J. G., Kuczynski, J., Stombaugh, J., Bittinger, K., Bushman, F. D., Costello, E. K., etal. (2010). QIIME allows analysis of high-throughput community sequencing data. Nat. Methods 7, 335-336. doi: 10.1038/nmeth.f.303

Carpenter, E. J., Lin, S., and Capone, D. G. (2000). Bacterial activity in South Pole snow. Appl. Environ. Microbiol. 66, 4514-4517. doi: 10.1128/AEM.66.10.45144517.2000

Cary, S. C., McDonald, I. R., Barrett, J. E., and Cowan, D. A. (2010). On the rocks: the microbiology of Antarctic Dry Valley soils. Nat. Rev. Microbiol. 8, 129-138. doi: $10.1038 /$ nrmicro2281

Claridge, G. G. C., and Campbell, I. B. (1977). The salts in Antarctic soils, their distribution and relationship to soil processes. Soil Sci. 123:377. doi: 10.1097/00010694-197706000-00006

Clarke, K. R., and Gorley, R. N. (2006). PRIMER v6: User Manual/Tutorial. Plymouth: PRIMER-E.

Cole, J. R., Wang, Q., Cardenas, E., Fish, J., Chai, B., Farris, R. J., et al. (2009). The Ribosomal Database Project: improved alignments and new tools for rRNA analysis. Nucleic Acids Res. 37, D141-D145. doi: 10.1093/nar/ gkn879

Culman, S. W., Bukowski, R., Gauch, H. G., Cadillo-Quiroz, H., and Buckley, D. H. (2009). T-REX: software for the processing and analysis of T-RFLP data. BMC Bioinformatics 10:171. doi: 10.1186/1471-2105-10-171 
Dana, G. L., Whartan, R. A., and Dubayha, R. (1998). "Solar radiation in the McMurdo Dry Valleys, Antarctica," in Ecosystem Dynamics in a Polar Desert, ed. J. C. Priscu (Washington, DC: AGU), 39-64.

Danovaro, R., Luna, G. M., Dell'Anno, A., and Pietrangeli, B. (2006). Comparison of two fingerprinting techniques, terminal restriction fragment length polymorphism and automated ribosomal intergenic spacer analysis, for determination of bacterial diversity in aquatic environments. Appl. Environ. Microbiol. 72, 5982-5989. doi: 10.1128/AEM.01361-06

Dartnell, L. R., Hunter, S. J., Lovell, K. V., Coates, A. J., and Ward, J. M. (2010). Low-temperature ionizing radiation resistance of Deinococcus radiodurans and Antarctic Dry Valley bacteria. Astrobiology 10, 717-732. doi: 10.1089/ast.2009.0439

de la Torre, J. R., Goebel, B. M., Friedmann, E. I., and Pace, N. R. (2003). Microbial diversity of cryptoendolithic communities from the McMurdo Dry Valleys, Antarctica. Appl. Environ. Microbiol. 69, 3858-3867. doi: 10.1128/AEM.69.7.3858-3867.2003

Díez, B., Pedrós-Alió, C., Marsh, T. L., and Massana, R. (2001). Application of denaturing gradient gel electrophoresis (DGGE) to study the diversity of marine picoeukaryotic assemblages and comparison of DGGE with other molecular techniques. Appl. Environ. Microbiol. 67, 2942-2951. doi: 10.1128/AEM.67.7.2942-2951.2001

Doran, P. T., McKay, C. P., Clow, G. D., Dana, G. L., Fountain, A. G., Nylen, T., et al. (2002). Valley floor climate observations from the McMurdo Dry Valleys, Antarctica, 1986-2000. J. Geophys. Res. Atmos. 107:4772. doi: 10.1029/2001JD002045

Fell, J. W., Scorzetti, G., Connell, L., and Craig, S. (2006). Biodiversity of microeukaryotes in Antarctic Dry Valley soils with 5\% soil moisture. Soil Biol. Biochem. 38, 3107-3119. doi: 10.1016/j.soilbio.2006.01.014

Foissner, W. (1974). Two remarkable soil spathidiids (Ciliophora: Haptorida), Arcuospathidium pachyoplites sp. n. and Spathidium faurefremieti nom. n. Acta Protozool. 42, 145-159. doi: 10.2307/302397

Franzmann, P. D. (1996). Examination of Antarctic prokaryotic diversity through molecular comparisons. Biodivers. Conserv. 5, 1295-1305. doi: 10.1007/BF00051980

Friedmann, E. I. (ed.). (1993). Antarctic Microbiology. New York: Wiley \& Sons, Inc. Gooseff, M. N., Lyons, W. B., McKnight, D. M., Vaughn, B. H., Fountain, A. G., and Dowling, C. (2006). A stable isotopic investigation of a polar desert hydrologic system, McMurdo Dry Valleys, Antarctica. Arct. Antarct. Alp. Res. 38, 60-71. doi: 10.1657/1523-0430(2006)038[0060:ASIIOA]2.0.CO;2

Gooseff, M. N., McKnight, D. M., Runkel, R. L., and Vaughn, B. H. (2003). Determining long time-scale hyporheic zone flow paths in Antarctic streams. Hydrol. Process. 17, 1691-1710. doi: 10.1002/hyp.1210

Gordon, D. A., Priscu, J., and Giovannoni, S. (2000). Origin and phylogeny of microbes living in permanent Antarctic lake ice. Microb. Ecol. 39, 197-202.

Hopkins, D. W., Sparrow, A. D., Elberling, B., Gregorich, E. G., Novis, P. M., Greenfield, L. G., et al. (2006a). Carbon, nitrogen and temperature controls on microbial activity in soils from an Antarctic Dry Valley. Soil Biol. Biochem. 38, 3130-3140. doi: 10.1016/j.soilbio.2006.01.012

Hopkins, D. W., Sparrow, A. D., Novis, P. M., Gregorich, E. G., Elberling, B., and Greenfield, L. G. (2006b). Controls on the distribution of productivity and organic resources in Antarctic Dry Valley soils. Proc. Biol. Sci. 273, 2687-2695. doi: $10.1098 /$ rspb. 2006.3595

Howard-Williams, C., Priscu, J. C., and Vincent, W. F. (1989). Nitrogen dynamics in two Antarctic streams. Hydrobiologia 172, 51-61. doi: 10.1007/BF00031612

Johnson, R. M., Madden, J. M., and Swafford, J. R. (1978). “Taxonomy of Antarctic bacteria from soils and air primarily of the McMurdo Station and Victoria Land Dry Valley region," in Identification of Some Fungi from Soils and Air of Antarctica, ed. B. Parker (Washington, DC: American Geophysical Union), 35-64.

Kaplan, F., Lewis, L. A., Herburger, K., and Holzinger, A. (2013). Osmotic stress in Arctic and Antarctic strains of the green alga Zygnema (Zygnematales, Streptophyta): effects on photosynthesis and ultrastructure. Micron 44, 317-330. doi: 10.1016/j.micron.2012.08.004

Lee, C. K., Barbier, B. A., Bottos, E. M., McDonald, I. R., and Cary, S. C. (2012). The inter-valley soil comparative survey: the ecology of Dry Valley edaphic microbial communities. ISME J. 6, 1046-1057. doi: 10.1038/ismej.2011.170

Maszenan, A. M., Seviour, R. J., Patel, B. K. C., Rees, G. N., and McDougall, B. M. (1997). Amaricoccus gen. nov., a gram-negative coccus occurring in regular packages or tetrads, isolated from activated sludge biomass, and dof
Amaricoccus veronensis sp. nov., Amaricoccus tamworthensis sp. nov., Amaricoccus macauensis sp. nov., and A. Int. J. Syst. Bacteriol. 47, 727-734. doi: 10.1099/00207713-47-3-727

McKnight, D. M., Niyogi, D. K., Alger, A. S., Bomblies, A., Conovitz, P. A., and Tate, C. M. (1999). Dry valley streams in Antarctica: ecosystems waiting for water. Bioscience 49, 985-995. doi: 10.2307/1313732

McKnight, D. M., and Tate, C. M. (1997). Canada stream: a glacial meltwater stream in Taylor Valley, South Victoria Land, Antarctica. J. North Am. Benthol. Soc. 16, 14-17. doi: 10.2307/1468224

McKnight, D. M., Tate, C. M., Andrews, E. D., Niyogi, D. K., Cozzetto, K., Welch, K., et al. (2007). Reactivation of a cryptobiotic stream ecosystem in the McMurdo Dry Valleys, Antarctica: a long-term geomorphological experiment. Geomorphology 89, 186-204. doi: 10.1016/j.geomorph.2006.07.025

Møller, A. K., Søborg, D. A., Al-Soud, W. A., Sørensen, S. J., and Kroer, N. (2013). Bacterial community structure in High-Arctic snow and freshwater as revealed by pyrosequencing of $16 \mathrm{~S}$ rRNA genes and cultivation. Polar Res. 32:17390. doi: 10.3402/polar.v32i0.17390

Moorhead, D. L., Barrett, J. E., Virginia, R. A., Wall, D. H., and Porazinska, D. (2003). Organic matter and soil biota of upland wetlands in Taylor Valley, Antarctica. Polar Biol. 26, 567-576. doi: 10.1007/s00300-003-0524-x

Niederberger, T. D., McDonald, I. R., Hacker, A. L., Soo, R. M., Barrett, J. E., Wall, D. H., et al. (2008). Microbial community composition in soils of Northern Victoria Land, Antarctica. Environ. Microbiol. 10, 1713-1724. doi: 10.1111/j.14622920.2008.01593.x

Niederberger, T. D., Sohm, J. A., Tirindelli, J., Gunderson, T., Capone, D. G., Carpenter, E., et al. (2012). Diverse and highly active diazotrophic assemblages inhabit ephermally wetted soils of the Antarctic Dry Valleys. FEMS Microbiol. Ecol. 82, 376-390. doi: 10.1111/j.1574-6941.2012.01390.x

Novis, P. M., Whitehead, D., Gregorich, E. G., Hunt, J. E., Sparrow, A. D., Hopkins, D. W., et al. (2007). Annual carbon fixation in terrestrial populations of Nostoc commune (Cyanobacteria) from an Antarctic Dry Valley is driven by temperature regime. Glob. Chang. Biol. 13, 1224-1237. doi: 10.1111/j.1365-2486.2007. 01354.x

Pointing, S. B., Chan, Y., Lacap, D. C., Lau, M. C. Y., Jurgens, J. A., and Farrell, R. L. (2009). Highly specialized microbial diversity in hyper-arid polar desert. Proc. Natl. Acad. Sci. U.S.A. 106, 19964-19969. doi: 10.1073/pnas.0908274106

Priscu, J. C., Fritsen, C. H., Adams, E. E., Giovannoni, S. J., Paerl, H. W., McKay, C. P., et al. (1998). Perennial Antarctic lake ice: an oasis for life in a polar desert. Science 280, 2095-2098. doi: 10.1126/science.280.5372.2095

Pruesse, E., Quast, C., Knittel, K., Fuchs, B. M., Ludwig, W., Peplies, J., et al. (2007). SILVA: a comprehensive online resource for quality checked and aligned ribosomal RNA sequence data compatible with ARB. Nucleic Acids Res. 35, 71887196. doi: 10.1093/nar/gkm864

Ramsay, A. J., and Stannard, R. E. (1986). Numbers and viability of bacteria in ornithogenic soils of Antarctica. Polar Biol. 5, 195-198. doi: 10.1007/BF00446086

Ruisi, S., Barreca, D., Selbmann, L., Zucconi, L., and Onofri, S. (2007). Fungi in Antarctica. Rev. Environ. Sci. Biotechnol. 6, 127-141. doi: 10.1007/s11157-0069107-y

Runkel, R. L., McKnight, D. M., and Andrews, E. D. (1998). Analysis of transient storage subject to unsteady flow: diel flow variation in an Antarctic stream. J. North Am. Benthol. Soc. 17, 143-154. doi: 10.2307/1467958

Schloss, P. D., Westcott, S. L., Ryabin, T., Hall, J. R., Hartmann, M., Hollister, E. B., et al. (2009). Introducing mothur: open-source, platform-independent, community-supported software for describing and comparing microbial communities. Appl. Environ. Microbiol. 75, 7537-7541. doi: 10.1128/AEM.01541-09 Shravage, B. V., Dayananda, K. M., Patole, M. S., and Shouche, Y. S. (2007). Molecular microbial diversity of a soil sample and detection of ammonia oxidizers from Cape Evans, Mcmurdo Dry Valley, Antarctica. Microbiol. Res. 162, 15-25. doi: 10.1016/j.micres.2006.01.005

Sjoling, S., and Cowan, D. A. (2003). High 16S rDNA bacterial diversity in glacial meltwater lake sediment, Bratina Island, Antarctica. Extremophiles 7, 275-282. doi: 10.1007/s00792-003-0321-z

Smith, J. L., Barrett, J. E., Tusnády, G., Rejtö, L., and Cary, S. C. (2010). Resolving environmental drivers of microbial diversity in Antarctic soils. Antarct. Sci. 22, 673-680. doi: 10.1017/S0954102010000763

Smith, J., Tow, L., Stafford, W., Cary, C., and Cowan, D. (2006). Bacterial diversity in three different Antarctic cold desert mineral soils. Microb. Ecol. 51, 413-421. doi: $10.1007 /$ s00248-006-9022-3 
Smith, R., Prezelin, B., Baker, K., Bidigare, R., Boucher, N., Coley, T., et al. (1992). Ozone depletion: ultraviolet radiation and phytoplankton biology in antarctic waters. Science 255, 952-959. doi: 10.1126/science.1546292

Soo, R. M., Wood, S. A., Grzymski, J. J., McDonald, I. R., and Cary, S. C. (2009). Microbial biodiversity of thermophilic communities in hot mineral soils of Tramway Ridge, Mount Erebus, Antarctica. Environ. Microbiol. 11, 715-728. doi: 10.1111/j.1462-2920.2009.01859.x

Stanish, L. F., O’Neill, S. P., Gonzalez, A., Legg, T. M., Knelman, J., McKnight, D. M., et al. (2013). Bacteria and diatom co-occurrence patterns in microbial mats from polar desert streams. Environ. Microbiol. 15, 1115-1131. doi: 10.1111/j.14622920.2012.02872.x

Thompson, D. C., Craig, R. M., and Bromley, A. M. (1971). Climate and surface heat balance in an Antarctic Dry Valley. New Zealand J. Sci. 14, 245-251.

Tiao, G., Lee, C. K., McDonald, I. R., Cowan, D. A., and Cary, S. C. (2012). Rapid microbial response to the presence of an ancient relic in the Antarctic Dry Valleys. Nat. Commun. 3:660. doi: 10.1038/ncomms1645

Van Trappen, S., Vandecandelaere, I., Mergaert, J., and Swings, J. (2004). Gillisia limnaea gen. nov., sp. nov., a new member of the family Flavobacteriaceae isolated from a microbial mat in Lake Fryxell, Antarctica. Int. J. Syst. Evol. Microbiol. 54, 445-448. doi: 10.1099/ijs.0.02922-0

Vincent, W. F. (1988). Microbial Ecosystems of Antarctica. New York: Cambridge University Press.

Vincent, W. F. (2000). "Cyanobacterial dominance in the polar regions," in The Ecology of Cyanobacteria, eds B. A. Whitton and M. Potts (Dordrecht: Kluwer Academic Publishers), 321-340.

Vincent, W. F., Downes, M. T., Castenholtz, R. W., and Howard-Williams, C. (1993). Community structure and pigment organisation of cyanobacteriadominated microbial mats in Antarctica. Eur. J. Phycol. 28, 213-221. doi: 10.1080/09670269300650321

Vincent, W. F., and Howard-Williams, C. (1986). Antarctic stream ecosystems: physiological ecology of a blue-green algal epilithon. Freshw. Biol. 16, 219-233. doi: 10.1111/j.1365-2427.1986.tb00966.x

Virginia, R. A., and Wall, D. H. (1999). How soils structure communities in the Antarctic dry Valleys. Bioscience 49, 973-983. doi: 10.2307/ 1313731

Vishniac, V. W. (1993). "The microbiology of Antarctic soils," in Antarctic Microbiology, ed. E. Friedmann (New York: Wiley-Liss), 297-342.

Vishniac, V. W., and Mainzer, S. E. (1972). Soil microbiology studied in situ in the Dry Valleys of Antarctica. Antarct. J. US 7, 88-89.
Wood, S. A., Rueckert, A., Cowan, D. A., and Cary, S. C. (2008). Sources of edaphic cyanobacterial diversity in the Dry Valleys of Eastern Antarctica. ISME J. 2, 308320. doi: 10.1038/ismej.2007.104

Wynn-Williams, D. D. (1990). Ecological aspects of Antarctic microbiology. Adv. Microb. Ecol. 11, 71-146. doi: 10.1007/978-1-4684-7612-5_3

Wynn-Williams, D. D. (1996). Antarctic microbial diversity: the basis of polar ecosystem processes. Biodivers. Conserv. 5, 1271-1293. doi: 10.1007/BF00051979

Yurkov, V., Stackebrandt, E., Holmes, A., Fuerst, J. A., Hugenholtz, P., Golecki, J., et al. (1994). Phylogenetic positions of novel aerobic, bacteriochlorophyll acontaining bacteria and description of Roseococcus thiosulfatophilus gen. nov., sp. nov., Erythromicrobium ramosum gen. nov., sp. nov., and Erythrobacter litoralis sp. nov. Int. J. Syst. Bacteriol. 44, 427-434. doi: 10.1099/00207713-44-3-427

Zeglin, L., Dahm, C., Barrett, J., Gooseff, M., Fitpatrick, S., and Takacs-Vesbach, C. (2011). Bacterial community structure along moisture gradients in the parafluvial sediments of two ephemeral desert streams. Microb. Ecol. 61, 543-556. doi: 10.1007/s00248-010-9782-7

Zhang, Y.-Q., Yu, L.-Y., Wang, D., Liu, H.-Y., Sun, C.-H., Jiang, W., et al. (2008). Roseomonas vinacea sp. nov., a Gram-negative coccobacillus isolated from a soil sample. Int. J. Syst. Evol. Microbiol. 58, 2070-2074. doi: 10.1099/ijs.0.65789-0

Conflict of Interest Statement: The authors declare that the research was conducted in the absence of any commercial or financial relationships that could be construed as a potential conflict of interest.

Received: 03 November 2014; accepted: 05 January 2015; published online: 28 January 2015.

Citation: Niederberger TD, Sohm JA, Gunderson TE, Parker AE, Tirindelli J, Capone DG, Carpenter EJ and Cary SC (2015) Microbial community composition of transiently wetted Antarctic Dry Valley soils. Front. Microbiol. 6:9. doi: 10.3389/fmicb.2015.00009

This article was submitted to Terrestrial Microbiology, a section of the journal Frontiers in Microbiology.

Copyright (c) 2015 Niederberger, Sohm, Gunderson, Parker, Tirindelli, Capone, Carpenter and Cary. This is an open-access article distributed under the terms of the Creative Commons Attribution License (CC BY). The use, distribution or reproduction in other forums is permitted, provided the original author(s) or licensor are credited and that the original publication in this journal is cited, in accordance with accepted academic practice. No use, distribution or reproduction is permitted which does not comply with these terms. 